Georgia State University

ScholarWorks @ Georgia State University

\title{
Theorising Suburban Infrastructure: A Framework for Critical and Comparative Analysis
}

Jean-Paul Addie

Georgia State University, jaddie@gsu.edu

Follow this and additional works at: https://scholarworks.gsu.edu/urban_studies_institute

Part of the Urban Studies and Planning Commons

\section{Recommended Citation}

Addie, Jean-Paul, "Theorising Suburban Infrastructure: A Framework for Critical and Comparative Analysis" (2016). USI Publications. 17. doi: https://doi.org/10.1111/tran.12121

This Article is brought to you for free and open access by the Urban Studies Institute at ScholarWorks @ Georgia State University. It has been accepted for inclusion in USI Publications by an authorized administrator of ScholarWorks@ Georgia State University. For more information, please contact scholarworks@gsu.edu. 


\title{
THEORIZING SUBURBAN INFRASTRUCTURE: A FRAMEWORK FOR CRITICAL AND COMPARATIVE ANALYSIS
}

\author{
Jean-Paul D. Addie \\ Department of Geography \\ University College London \\ Pearson Building, Gower Street \\ London, WC1E 6BT \\ j.addie@ucl.ac.uk
}

Accepted by Transactions of the Institute of British Geographers

February 2016

\begin{abstract}
Suburban infrastructure holds a position of increasing geographic, political and conceptual importance in a rapidly urbanizing world. However, the analytical significance of 'suburban infrastructure' risks becoming bogged down as a chaotic concept amidst the maelstrom of contemporary peripheral urban growth and the explosion of interest in infrastructure in critical urban studies. This paper develops an open and flexible comparative theory of suburban infrastructure. I eschew concerns with definitional bounding to focus analytical attention on the relations between 'the suburban' (broadly considered) and multiple hard and soft infrastructures. These relations are captured in two 'three-dimensional' dialectical triads: the first unpacks the modalities of infrastructure in, for, and of suburbs; the second discloses the political economic processes (suburbanization), lived experience (suburbanism), and dynamics of mediation internalized by particular suburban infrastructures. Bringing these conceptual frames together constructs a nine-cell matrix that: (1) functions as a heuristic device providing conceptual clarity when discussing the suburbanity of infrastructures; (2) promotes comparative analysis across diverse global suburban contexts; and (3) develops tools to foreground the dialectical relations internalized in the concrete sociospatial modalities of suburban infrastructure. The paper shows that suburban infrastructure can only ever be partially suburban as a result of it co-constituted and over-determined production. I conclude by suggesting how the proposed approach may be mobilized to reimagine and reclaim suburban infrastructure as a crucial context and vital mechanism underpinning a progressive polycentric suburban spatial polity.
\end{abstract}

Keywords: Comparative urbanism; Dialectical urbanism; Global suburbs; Infrastructure; Suburbanism; Suburbanization. 
Across the globe, infrastructure is the lifeblood of prosperity and economic confidence in the $21^{\text {st }}$ century (Miller 2013, 4).

What, if anything, is held in common across infrastructures as diverse as waste, roads, and trains? And between urban contexts as different as Jakarta, Mumbai, Kampala, Newcastle, and Ramallah? (Graham and McFarlane 2015, 12-13).

\section{Introduction: (Beyond) 'chaotic concepts'}

Opening the 'black box' of infrastructure has rapidly emerged as a major concern for geographers and urban scholars. More than banal engineered artefacts and technological systems, a robust literature now examines infrastructure as a critical object of analysis to think through the politics, ecology, social relations, and everyday experiences of urban life (Angelo and Hentschel 2015; Coutard 2008; Easterling 2014; Graham and Marvin 2001; Graham and McFarlane 2015; Swyngedouw 2004; Young et al. 2011). Urban infrastructures are contested, power-laden elements of the urban fabric. As such, McFarlane and Rutherford $(2008,366)$ argue, what is often at stake in these discussions "is not simply the provision of infrastructure, but the conceptualization of the city, and the nature of social justice". Building privileged infrastructure systems may be heralded as state spatial strategy to enhance the territorial competitiveness and resilience of metropolitan regions (Bjorvatn 2000; Miller 2013), but access to urban infrastructure, the resource flows it mediates, and the experience of its failures are highly uneven and unequal (Graham 2010). This assertion becomes increasingly pertinent, and problematic, as the on-going rapid urbanization of the planet necessitates massive investment in developing the core infrastructures of emerging urban societies and upgrading the antiquated and over-capacity systems of many metropolitan areas. Much of this infrastructural investment is likely to drive the continued extension of urban spatial forms through the construction of large-scale energy, transportation, ICT, water, and waste systems, or support swiftly expanding 
informal development and settlement patterns surrounding sprawling global megacities (Keil 2013). Infrastructure established the conditions for the historical expansion of urban centers and the integration/marginalization of peripheral communities into the wider urban fabric (Beauregard 2006;

Gandy, 2003; Harris 2006; Law, 2012; Fishman 1987). The urban periphery remains a crucial frontier for both infrastructural innovation and stress. And as non-central urban growth occupies an increasingly essential role in the urban process, suburban infrastructure will deeply shape the future potentialities and challenges of cities, suburbs, and an urbanizing world more broadly.

A preponderance of current research on suburban infrastructure focuses on its role in facilitating suburban sprawl, and its potential to retrofit these auto-centric landscapes towards a denser form and more compact mode of peripheral urban development; that is, make them more efficient and more urban (e.g. Burchell et al. 2005; D’Hooghe 2011; Grant et al. 2013; MacCleery et al. 2012; Mees 2010). Critiques of the banality of the archetypal American residential suburb and warnings surrounding 'peak oil' point to a nascent desire, and the potential necessity, of transforming suburban development patterns and lifestyles away from the low-density, auto-dependent, and government subsidized suburbia of the postwar period. Such narratives, though, not only tend to downplay the persistence of technological and political interventions in supporting automobileenabled suburban living (Filion 2015), but overlook the highly differentiated and adaptable nature of diverse global suburban environments. As infrastructure systems are produced, overlaid, and restructured in urban peripheries, the emergent suburban landscapes they co-produce do not hold the same functional logics or spatial practices as the historical center city or ideational conceptions abstracted from the postwar North American suburb (Quinby 2011). We therefore need to pay concerted attention to how we think about infrastructure in dynamic suburban environments and how we approach the knowledge and experience of suburban infrastructure itself. 
Suburban infrastructure, though, presents theoretical and methodological challenges for critical and comparative urban studies, in large part because the notion brings together two essentially 'chaotic concepts'. 'The sheer variety of global suburban constellations (in nature, form, and spatiotemporal development) inhibits the construction of universal or all-encompassing definitions of 'the suburbs' (Phelps et al. 2010). On one hand a number of new conceptual languages have emerged to grapple with the specificities of highly differentiated suburban spaces, including now classic accounts of 'edge cities' (Garreau 1991), 'ethnoburbs’ (Li 2009), 'metroburbia' (Knox 2008), 'post-suburbia' (Teaford 1997) and the 'in-between city' (Sieverts 2003; Young et al. 2011). On the other, typologies grounded in broad characteristics, such as a peripherality, low-density, and newness (Harris 2010), morphological differentiation between urban, exurban, or rural metropolitan forms (Stanilov and Scheer 2004; Vaughan et al. 2009) or population type; dominant politics; main actors; and morphological change (Charmes and Keil 2015), have struggled to fully encompass the dynamic, ephemeral, and transitory characteristics of such peripheral urbanization. The pluralized, contextual, and interconnected nature of contemporary suburbs poses an epistemological question as to whether there anything analytically distinct about 'suburban infrastructure', or the social, technical, and political regimes that singularize the suburban moment in their production, governance, or use.

Similarly, the growth of interdisciplinary engagements with urban infrastructure has considerably broadened its scope as an analytical concept and object of analysis. While usually understood as the key material, technological, and now digital assets of cities, infrastructure is also utilized as a frame to examine the myriad social arrangements that condition the capacities of people in place: from the economic and regulatory regimes of global infrastructure finance (Siemiatycki

\footnotetext{
${ }^{1}$ Chaotic concepts are uncritical abstractions that construct an object of analysis a priori, without familiarity with the elements on which it rests. Such bad abstraction "arbitrarily [divide] the indivisible and/or [lump] together the unrelated and the inessential, thereby 'carving up' the object of study with little or no regard for its structure and form” (Sayer 1992, 138). Once chaotic concepts are ascribed causal power, diverse and unrelated elements are erroneously assumed to share essential commonalities or causally significant properties.
} 
2013; Torrance 2008) to informal everyday rituals and ideoloigcal imaginaries (Amin 2014; Chattopadhyay 2012; Dourish and Bell 2007; Simone 2004). The extended definitional capacity of such technical (hard) and social (soft) infrastructures has spurred innovative investigations into the networked nature of contemporary urbanism, but it has also opened the risk of theoretical overextension and misuse (Howe et al. 2015). Graham and McFarlane, ruminating on the questions posed in the epitaph, observe that in the absence of a versatile comparative theory of urban infrastructure there is "a tendency for infrastructure studies to focus on particular infrastructures... [with] little held in common beyond infrastructure itself as a set of material processes" $(2015,13)$. Post-colonial urbanists have responded to this challenge by calling for comparative analyses more attuned to difference than similarity and subsequently adept at exposing overgeneralized theories abstracted from limited cases in the Global North and guarding against the top-down imposition of policy agendas over the everyday knowledges of urban inhabitants (McFarlane et al. 2014; Robinson 2011). Strong theorization and rigorous methodologies, however, continue to be essential if we are to conduct such comparative work and prevent chaotic conceptions robbing 'suburban infrastructure' of its analytical utility and explanatory capacity (see Kantor and Savitch 2005).

This paper develops a comparative theory of suburban infrastructure capable of supporting critical and comparative urban geographic analysis. I am not concerned with the task of defining 'suburban infrastructure' or enveloping all suburban forms within a totalizing theory. Rather, I seek to identify flexible conceptual and methodological innovations by focusing on the distinct relations between any number of hard and soft infrastructures and the production, governance, and experience of dynamic, highly variegated suburban environments. My argument is built around two conceptual triads: the first unpacks the modalities of infrastructures as they exist in, for, and of suburbs (broadly understood as the landscapes of extended urbanization); the second discloses the political economic processes (suburbanization), lived experiences (suburbanisms), and dynamics of 
mediation internalized by particular suburban infrastructures. The moments within each triad are interconnected through a relational 'three-dimensional dialectic' so that rather than each binary being resolved through sublation, they coexist in conflict or alliance (Schmid 2008; via Lefebvre 1991, 39). The categories presented are neither mutually exclusive nor ontologically separate. Instead, they offer differing epistemological vantage points that illuminate suburban infrastructure's divergent characteristics and disclose tensions between their structuring imperatives, experiences, and politics.

Drawing the two triads together into a nine-cell matrix establishes an open and adaptable heuristic framework to unpack and conceptualize the geography of suburbanity presented by specific infrastructures and their associated actors, economies, and cultures. This approach take seriously the need to account for both the highly differentiated landscapes and endogenous processes of global suburbia, and the importance of developing a strong theorization of suburban infrastructure. Mobilizing the matrix as a methodological apparatus provides concepts and mechanisms to facilitate detailed comparative analysis within and across global suburban contexts. As such, it provides a rejoinder to post-colonial urbanism's focus on comparing 'provincial' knowledge and learning from difference (Robinson 2011; 2015) and calls for a new epistemology of the 'planetary' urban posted at a higher level of abstraction (Brenner and Schmid 2015). The dialectical method underlying this theoretical schematic foregrounds the social relations internalized in the concrete forms, spatial configurations, and governance of suburban infrastructures. Through the paper I argue that suburbanization processes do not exist in isolation but instead may assume 'ecological dominance' relative to other social relations (following Jessop 2000). In concluding, I assert that viewing suburbanity of infrastructure as contingent upon its imbricated and co-constituted relations to other urbanization processes has profound resonance for questions of suburban spatial politics and the possibility of articulating a 'right to the suburbs'. 


\section{Seeing infrastructure through suburbs, and suburbs through infrastructure}

\section{Suburban infrastructure as artifacts and systems}

I begin from the proposition that the suburbanity of infrastructure derives from more than its location in a suburban place. As technical, social, political, cultural, and economic entities, infrastructures invoke a multifaceted and interconnected amalgam of sociospatial relations. After Jessop et al. (2008), infrastructures terriorialize as they bound and enclose (e.g. materially and symbolically separating neighborhoods). They also act as place-makers that embedded flows in particular places, render social structures and relations proximate, and can often function as symbolic markers that codify representations of space. These sociospatial relations clearly tie infrastructure to the dynamics of the state, real estate markets, and financial capital. Infrastructures facilitate different scales of mobility and governance through the application of new (or reformed) technologies (both material and of power). Yet uneven access to infrastructure discloses dialectics of inclusion/exclusion fostered by such reticulated networks. Nodal connectivity integrates space into distinct topological landscapes that internalize power geometries and processes of uneven development at the same time as they make multi-locality life possible. In order to grapple with the spatial specificity of suburban infrastructure, we need to unpack the manner in which infrastructure may be: (1) physically embedded in suburban landscapes; (2) produced and performed through placebased suburban governance and sociospatial dynamics; and (3) supportive of suburbanization and suburban ways of life. In other words, we can consider a tripartite division between suburban infrastructure as artifacts and systems in, of, and for suburbs (Figure 1):

\section{[FIGURE 1 HERE]}

- Infrastructure in suburbs are principally suburban as a consequence of their physical location in a suburban environment. Such infrastructures may be embedded in suburban places but the 
flows they territorialize and their primary functional logics are not contingent on this suburban positioning. Rather, higher order restructuring aligns them to alternative scales of governance and mobility, and political economies conditioned elsewhere. We can consider the infrastructures facilitating the suburbanization of global distribution and logistics industries - intermodal terminals, international cargo airports, major trucking highways, extended landscapes of warehousing and distribution facilities - as a case in point (see Keil and Young 2008). The state and private actors can take advantage of greenfield development on the urban fringe where road and airport connections are ubiquitous and large plots of cheap real estate are readily available. But these infrastructures and industrial facilities are clearly attuned to processes of globalization rather than essentially suburban in nature. The infrastructural moorings necessary to fix globalization processes in place are often massive in scale (Urry 2003). The space needed to move cars around an expressway corner at $70 \mathrm{mph}$ is immense. Suburban space and scale, then, do not register in the same way as in the urban core. Consequently, the physical presence of 'infrastructures in suburbs' - and the imperatives of global competitiveness guiding their planning, operation, and governance have a significant impact on the lived experience, development trajectories and spatial imaginaries of the suburbs that house them (see Addie 2014 for an discussion of this issue in relation to global airports). The suburbanization of global infrastructures can open economic development opportunities on the urban fringe, leading suburban municipalities to reframe planning their local planning decisions and developmental agendas (Cidell 2011). But it also risks exposing communities to negative externalities, vulnerabilities, and disruptions; notably in 'in-between' urban landscapes where competing uses and social practices can be hapahazardly assembled in dangerous proximity (Keil and Young 2009). 
- Infrastructure of suburbs, by contrast, are chiefly determined by suburban institutions, communities, landscapes, and governmentalities. They can arise through formal channels structured by local governance, funding, maintenance, and operation. Suburban municipal ownership - whether directly or through special taxing districts - can create particular infrastructure systems (e.g. local transport authorities, municipal water boards, forest preserves) that mobilize claims of power and authority over territories both near and far. ${ }^{2}$ Suburban transportation management authorities around Toronto have, for example, sought to institutionalize locally-organized carpooling and workplace shuttle programs to address the mobility challenges presented by a dispersed and sprawling landscape beyond the urban core (Smart Commute 2014). 'Infrastructures of suburbs' may also be developed through the informal arrangements and social practices adopted by users of suburban space; notably in response to deficiencies presented in infrastructure deserts. Examples of such appropriation and adaptation are instructively assessed in McFarlane et al.'s (2014) examination of informal sanitation in Mumbai's peripheral neighborhoods and Lo et al.'s (2015) account of the social vulnerabilities emerging at the nexus of low density, auto-dependence, and neoliberal governance in Toronto's outer suburbs. As they are essentially defined by distinct suburban governance regimes or ways of life, we can approach the 'infrastructure of suburbs' through the production, lived experience, or appropriation of networked space, and discourses that construct suburbs in relation to infrastructures that are normatively understood as 'suburban' - including auto-mobility as a suburban way of life (Walks 2015) and the linkages between homeownership, privatism and neoliberal spatial polity (Peck 2011).

- Infrastructure for suburbs are the material and social elements that shape the resource flows necessary to support suburban growth and ways of life. Processes of suburbanization are

\footnotetext{
2 These can be focused locally, or express imaginaries that position of suburbs in regional, national, or global settings.
} 
enabled through extended infrastructure networks that reach beyond suburbs as a territorially- or morphologically-defined spatial form. 'Infrastructure for suburbs' tie suburban space and society to central cities through systems supporting traditional economic, transport, and land-use patterns (a classic case being Warner's 1978 account of streetcar suburbs) and new infrastructural arrangements that condition the functional integration of polycentric urban regions. Here, we can view the contested takeover of municipal bus stops by 'Google buses' transporting tech workers from central San Francisco to offices in Silicon Valley as enabling the on-going suburbanization of employment in the Bay Area (Henderson 2015). At the same time, 'infrastructure for suburbs' extends into the exurban hinterlands of urban regions and beyond. The ecological footprint and metabolic demands of suburbs (for water, waste management, energy, labor power etc.) condition distant geographic landscapes - from reservoirs, water catchment management bodies, waste disposal, and national energy grids to the functionally segregated economic landscapes of the Canadian Tar Sands and Gulf oil fields - as infrastructural prerequisites for suburban development and reproduction (Atkinson 2007; Gandy 2003; Rees 1992; Soll 2012; Swyngedouw 2004). Infrastructure for suburbs' may thus be framed, following Brenner $(2014,15)$, as 'operational landscapes' of global suburbanization that extend well beyond bounded understandings of suburban form and social practice.

This initial schema is particularly useful in two regards. First, it forces our engagement with suburban infrastructure to transcend the territorial confines of 'the suburbs' themselves in empirical and conceptual terms. The distinct topological relations and propinquity disclosed by each categorization illuminates the necessity of incorporating multiple scales of analysis into any examination of suburban infrastructure. The palimpsest of infrastructures constituting ‘in-between’ urban spaces reveal an overlay of competing and conflicting scalar (dis)connectivities (Young et al. 2011) while, in 
contrast to a rhetoric of exclusions and secessionist politics, the metabolic and social demands of gated communities and elite enclaves render them highly porous and networked (Kaker 2014; Knox $2008,59)$. At the same time, while 'infrastructure in suburbs' might be aligned to broader scales of urban development, they still play a vital role in shaping the identity, functionality, and politics of individual suburbs by bounding, enclosing or dividing space. Second, it draws attention to questions of ownership, governance, and the material interests of social and political action. Since individual artefacts and specific systems may internalize multiple scales of urban development and rhythms of mobility, they can invoke distinct and competing political claims (e.g. around issues of NIMBYism versus the demands of regional competitiveness; taxpayers versus users; or conflicting imaginaries forwarded by competing state formations). As a result, infrastructures in, of, and for suburbs are not ontologically exclusive categories but serve to illuminate the diverse uses, relations, and ambiguities emergent across the sociotechnical geographies of global suburbia.

\section{Infrastructure and the suburban process}

Considering suburban infrastructures as things (broadly considered) generated and assembled relative to suburban space, though, only offers a partial viewpoint; one that does not adequately account for the (sub)urban processes giving rise to an ephemeral and transitory amalgam of highly differentiated landscapes (Keil, 2013, p. 9; Walks 2013a). Refocusing our attention on the processes internalized in particular infrastructural configurations points towards generative moments of social action and spaces of political practice. The focus on social action is pivotal. After all, it is social actors embedded in particular spatial forms, not the spatial form itself, who act - and enact - infrastructure as a site of political practice and contestation (Mayer 2008, 416). Suburbanization, therefore, needs to be viewed as an active and contested moment in the overall process of urban transformation (after 
Harvey 1996, 52). Here we can examine the political-economic, experiential, and mediatory dimensions of suburban infrastructure as a second set of epistemological vantage points (Figure 2):

\section{[FIGURE 2 HERE]}

- Infrastructure of suburbanization promotes and supports increases in non-central-city population and economic activity and the spatial expansion of urban constellations. The central focus here is infrastructure's role in the suburbanization of capital and the political-economic process that facilitate the capital production, consumption, and circulations underlying the form and function of suburban space. 'Infrastructures of suburbanization' include the construction and governance of pipelines, water systems, and transportation routes (Graham and Marvin 2001; Rutherford 2008) and the institutionalized mortgage regulations and financial 'innovations' (Knight and Sharma 2015; Walks 2014) that catalyze urban spatial expansion. This categorization draws our attention to the governance modalities of capital and the crucial role of the state as they are contextualized within broader trends and urbanization regimes - often in conjunction with the work of the development industry (Hayden 2003; also Hamel and Keil 2015). Changing accumulation, governance, and ecological regimes are interconnected with shifting infrastructural arrangements. The nexus of infrastructure and processes of crisis-induced urban restructuring provides a lens to analyze moments of technological transition and regulatory change around pressing environmental concerns at a number of scales (Dodson 2014). It also serves to illuminate the spatial preconditions necessary to established particular spatial fixes to the territorial restlessness of capital (Harvey 1985). 'Infrastructure of suburbanization' thus enables the realization of value from the production of suburban built environments, as well as forming markets for new wants and desires. Such processes were strongly in evidence during the postwar Fordist suburbanization of North America (including the material forms to 
suburban expansion and the institutions effectively subsidizing them), and can now be witnessed in the monumental acceleration of peripheral urbanization in China and beyond. Capitalism, however, renders obsolete the geographic landscapes formed to sustain accumulation at one point in time. Processes of creative destruction, enacted through contingent accumulation regimes and regulatory frameworks, are required to release overaccumulated and immobile fixed capital embedded in place as it is devalued and becomes a barrier to the realization of surplus value. These transformations are uneven and partial relative to the functional and symbolic recalibration of urban space.

- Infrastructure of suburbanism(s) are appropriated and repurposed through suburban spatial practice to construct qualitatively differentiated expressions of suburbanism as a way of life. They are experienced not just in place, but as a place. Since infrastructures require the coproduction of the subjects who make use of them - in fluid and unpredictable ways (Höhne, 2015) - 'infrastructures of suburbanism’ are integral to both the suburbanization of consciousness and the suburbanization of everyday life. They are further generative of governmentalities of authoritarian privatism or emancipation, to the extent that they interpolate inequalities, power relations, or the commodification of suburban space (Ekers et al. 2012). Here, it is useful to draw from Walks's (2013a, 1478-1483) abstraction of morphological and sociological moments of centrality (agglomeration/power), difference (juxtaposition/social diversity), and functionality (auto-mobility/domesticity-publicity). This schema not only exposes dialectical tensions between diverse suburbanisms but further highlights the extent to which the fabric of extended suburban landscapes is only experienced partially. The meaning, spatiality, and politics of suburban infrastructure differ for different people and social groups. We cannot talk of a singular mode of suburbanism but rather must account for the generation, co-presence, and contradictions of multiple suburbanisms (see Keil 
2013). New infrastructures bring about new forms of governance, knowledge, and subjectivity when introduced into the social realm. As Simone suggests:

People figure themselves out through figuring arrangements of materials, of designing what is available to them in formats and positions that enable them particular vantage points and ways of doing things. What it is possible for people to do with each other is largely a question of what it is that exists between them, and how this between can be shaped as active points of reference, connection and anchorage. Infrastructure exerts a force - not simply in the materials and energies it avails, but also the way it attracts people, draws them in, coalesces and expends their capacities $(2015,375)$.

'Infrastructure of suburbanism' are therefore attached to the formation and social reproduction of suburban lifestyles, and the construction of peripheral urban locales as distinct spaces of habitation, work, and play.

- Mediatory Infrastructure articulates suburban constellations within the multiscalar dynamics of contemporary urbanization. Drawing on Lefebvre's $(2003,80)$ theorization of the urban as a “mixed, mediator, or intermediary level”, suburban 'mediatory infrastructures' connect and resolve abstract yet essential social relations and the concrete spaces and practices of everyday life. They are sociomaterial practices that bridge between "two epistemological moments within an ontological unity: one we experience - [sub]urbanism [the lived experience of suburban space] - the other we don't - [sub]urbanization [as a political economic process] but we know it really exists nonetheless" (Merrifield 2002, 160). 'Mediatory infrastructures' shape our knowledge and experience of broader social dynamics and relations. Through practices of everyday life, interactions with infrastructure systems at the micro-scale constitute moments to abstract broader implications about macro-level processes and 
relations in space and over time (Angelo and Hentschel 2015). As Tonkiss $(2015,385)$ puts it "the material infrastructures that bind lives in common provide a physical counterpoint to the sociocultural bases for relation and circulation; the premises on which it becomes possible to interact, including the very idea that interaction is possible". 'Mediatory infrastructures', then, open analytic avenues to identify forces, spaces, and relations that might transcend the dialectical tensions between suburbanization (exchange-value) and suburbanism (use-value). In doing so, they highlight the transformative capacity of infrastructure to puncture new centralities (that can be multiple, fragmented, and overlaid) into seemingly rote and homogeneous landscapes. The mediatory processes internalized in suburban infrastructures may also expose the ways in which suburban space is physically, discursively, and politically embroiled into the wider spatiotemporal dynamics of urban development. For example, suburban municipalities might draw on national infrastructure funds (such as those rolled out following the 2008 Financial Crisis) to improve their local transportation systems and economic competitiveness, or, conversely be folded in to policy frameworks articulated at broader scales, as Cochrane et al. (2015) argue in the case of housing in southeast England.

\section{Mobilizing suburban infrastructure}

The conceptual triads presented above - one centered on material artifacts, institutions, and practices; one process-based - offer two possible ways to unpack 'suburban infrastructure' as complex concretions of spatially and temporally specific uses and social relations. ${ }^{3}$ Considering the

\footnotetext{
3 As an alternative framework, Tonkiss $(2015,384)$ provides a tripartite understanding of the economies of urban infrastructure, defined by "the moral economies implied by interactions with infrastructure, and with other people through infrastructure; the political economy of infrastructural investment, disinvestment and regulation variably instituted by state, corporate, communal and informal actors; and the auto-economies of everyday provision which rely on the embodied human labor - whether commodified or not - of infrastructural work".
} 
relationship between things and processes introduces an epistemological and ontological problem surrounding the relative prioritization of each, and indeed, "whether or not it is even possible to separate the process from the things embodied in it" (Harvey 1996, 50). Taking inspiration from Harvey's $(2006 ; 1996,50)$ dialectical methodology and schematic approach, there are productive insights to be gleaned by considering these triads in light of each other. The resulting nine-cell matrix, shown in Table 1, discloses the intersections of distinct modalities, materialities, and social relations internalized within particular suburban infrastructures. The content of the cells within this matrix are not exhaustive and their specific composition will depend on the particular geographies, concepts (of suburbs and infrastructure), and empirical cases under investigation.

\section{[TABLE 1 HERE]}

The utility of this matrix is, at first, heuristic. The goal here is to move away from 'chaotic' conceptualization when analyzing suburban infrastructure. Distinguishing moments along each theoretical axis enables the individuation of phenomena while highlighting the tensions between differing dimensions and their associated geographies. Reading across the rows in Table 1 promotes engagement with infrastructures beyond one-dimensional (technocratic or sociological) interpretations. To provide a simple(!) example, we can consider the contested expansion at London's Heathrow Airport as an infrastructure predominantly in suburban space (see Fernado 2015). Investment at Heathrow (opposed to other London airports, new or existing): is likely to (1) prompt the state and capital to invest in new ground transportation, warehousing, and intermodal facilities to cope with the expanded runway capacity (accelerated suburbanization); (2) increase noise and air pollution, thus disrupting the lived experience of suburban communities around the airport (reconfigured suburbanisms); while (3) integrating local markets and business interests more thoroughly into regional, national, and global economies (as a mediatory space). Concomitantly, reading down through the matrix's columns discloses how the political economic process of 
suburbanization, for instance, is imbricated in diverse, multiscalar infrastructures that themselves might be structured by functional logics that only partially (or inadvertently) catalyze the extension of metropolitan areas and non-central economic activity. In this context, the emergence of advanced logistics centers in the peripheries of city-regions represents not only the long-run suburbanization of industry, but the establishment of new points of global centrality facilitated by 'mediatory infrastructure' (for an extended discussion, see Cidell 2011).

Significantly, it is possible to read across the cells of the matrix in a non-hierarchical manner that prohibits focusing on a single modality. In contrast to recent engagements with urban infrastructure grounded in assemblage theory - which are concerned with how externally related objects and networks are brought together/dissolved, either randomly or under some logical principle, at particular junctures (e.g. Bennett 2005; Farias 2011; McFarlane 2011) - imagining each moment within the matrix as internally related to all the others exposes contradictions between elements and positions suburban infrastructure as a setting for, and object of, social struggle (Ollman 2003). This is particularly important for explaining how different social groups can hold widely differing perspectives on, and politics of, infrastructure and as a result identifying moments for political intervention and mobilization. As the suburban moment is perceived, conceived, and lived in partial and fragmented ways by different people at different moments, juxtaposing the multiple dimensions of suburban infrastructure opens alternative epistemological lenses to unpack the dialectical relations and points of tension internalized within the production of the suburban itself. The conflicting mobility requirements of global capital, local urban inhabitants, and new metropolitan territorialities, which Keil and Young (2008) demonstrate in Toronto, have resulted in a bifurcation between premium infrastructure networks and underserved local transit service. At the same time, the coupling of infrastructure investment with gentrifying urban development programs prioritizes urbanization as an accumulation regime over the lived experience for inhabitants in 
marginalized spaces of the urban periphery, whether tied to the production of mega-event stadia in Brazil, vast skyscraper projects acting as wells for surplus capital in Dubai and China, or the development of regional and commuter rail networks around Paris.

Tensions can be temporal as well as spatial, both within and across cells. We can theorize transitions between prevailing 'infrastructures of suburbanization' or between the integrating functions of 'mediatory infrastructure'. Beauregard (2006), for instance, has argued accelerated suburbanization in the postwar United States was premised upon a shift form 'distributive' growth to a 'parasitic urbanization' whereby suburbs fed off of government expenditures on infrastructure and re-regulated mortgage financing at the expense of hollowed-out older central cities. Walks (2013b) identifies a comparable postwar transition from the production and consumption of hard suburban infrastructure (new highways, housing etc.) supporting Fordist accumulation to a recalibrated accumulation regime based on auto-mobility and the financialization of suburban infrastructure. The subsequent generation of fictitious capital tied to homeownership, automobile loans, and other forms of household indebtedness since the late-1970s, he argues, has led both rising socioeconomic inequality and the suburbs becoming most indebted places in Canadian cities.

Developing from the analysis of particular artifacts and systems, the conceptual triads presented above may be deployed as a comparative means to analyze suburban infrastructures across diverse geographical, technological, and conceptual contexts. Focusing on the relations between the suburban and infrastructure directs investigations towards common and transferable abstractions founded upon sociospatial relations, rather than the contingent attributes of entities in isolation and the contextual specificity of particular locales. In response to Graham and McFarlane (2015, 13), I argue that it is these relations that are held in common across suburban infrastructures. This is not the top-down application of theory abstracted from a limited few cases, but a conceptual framework and methodological apparatus aimed at ensuring we are not simply placing two cases together or 
comparing suburban apples and infrastructural oranges. Suburban infrastructure may be viewed as in, of, or for suburbs and internalize processes of suburbanization, suburbanisms, and mediatory functions regardless of whether they are airports, roads, pipelines, fiber-optic cables, sanitation systems, cultural norms, or governance institutions, and tied to edge cities, post-suburbs, in-between spaces, or ethnoburbs in the Global North or South. Because the content of the theoretical matrix are dependent via concrete empirical investigation, it forms a framework to compare such differentiated suburban and infrastructural geographies (and their connections to the state, capital, and everyday life) in an analytically rigorous way that still accommodates epistemological reflexivity.

Finally, it is vital to note how differentiating the theoretical dimensions of suburbanity not only deepens our understanding of the ways in which infrastructure relate to suburban space and society, but it indicates that their suburbanity is, in many regards, only a partial element of the relations and processes they internalize. 'Infrastructure in suburbs', as I have suggested, remain conditioned by alternatively scaled mobilities and political economies while 'mediatory infrastructure' interconnect different social, spatial, and scalar relations. In this context, we can adapt an argument forwarded by Jessop (2000) in regards to global capitalism, to posit that suburban processes may realize 'ecological dominance' relative to infrastructural artifacts and systems (or not, as the suburban moment may only be a marginal element), but they do not 'dominate' other sociospatial dynamics involved in their co-production. For Jessop, extending ecological dominance from evolutionary theory to the realm of social systems implies the capacity of one social system "to imprint its developmental logics on other systems' operations... to a greater extent than the latter can impose their respective logics on that system" (ibid, 329). Applying this argument to suburban infrastructure forces us to consider the extent to which the suburban developmental and structuring logics internalized within an infrastructure's production, governance, or use may assert itself over, say, the requirements of global capital, national regulatory regimes, or the connectivities of virtual space. 
These relationships are always relative, contingent, and co-constituted with processes operating across other spaces and at other geographic scales.

Understanding the suburbanity of infrastructure via ecological dominance consequently presents a rejoinder to the argument that 'planetary urbanization' "charts the final frontier, the telos of any earthly spatial fix" (Merrifield 2013, 6). This is not to reject the notion that "even spaces that lie well beyond the traditional city cores and suburban peripheries... have become parts of the worldwide urban fabric" (Brenner and Schmid 2014, 163). Indeed, I have forwarded the concept of 'infrastructure for suburbs' as a means to analyze “the imprint and operationality of [sub]urban processes on the planetary landscape” (Brenner 2014, 15). But working at a more concrete level of abstraction (while remaining sympathetic to the underlying Lefebvrian foundations of the processoriented 'planetary urbanization' scholarship) provides a language and conceptual approach to introduce a more nuanced reading of the extension of suburban relations. In contrast to the totalizing, teleological discourse of the 'planetization of the urban', it points to the extension of suburban processes and relations and asserts their necessary variations as they interact with systems that are not subsumed within a universalizing logic of urbanization. We can consider, for instance, how the Canadian Tar Sands, or the Amazon rainforest, are produced as operational landscapes and made profitable through processes of global suburbanization through resource extraction, commodification, incorporation into the world market etc. (that is, as 'infrastructure for suburbs') but in manner that does not suggest the suburbanity imbued here essentially renders them as wholly suburbanized. As a result, the process, and extent to, which infrastructures are suburban in differing technological, social, and geographic contexts opens potentially constructive avenues for future empirical and comparative investigation. 


\section{Conclusion}

This paper has developed a critical and comparative theory of suburban infrastructure. I have argued that what is held in common between diverse suburban environments and distinct infrastructural systems are the relations internalized within particular suburban infrastructures. In theorizing these relations through a complementary framework of infrastructure in/of/for suburbs and infrastructure of suburbanization/suburbanism/mediation, I have presented an approach that recognizes and engages the unpredictable and over-determined nature of both suburban infrastructure and suburban space. This is not to suggest we arrive at a normative, essential, or readily transferable definition of 'suburban infrastructure'. Specific infrastructural forms and arrangements are characteristically multifaceted and multiscalar. They are constructed by complex governance regimes, contested by diverse stakeholders, and are generative of distinct social norms. Rather, I have suggested that infrastructure's suburbanity should be assessed relative to the 'ecological dominance' of suburban sociospatial relations in their production, governance, and use. Concrete articulations of suburban infrastructure are highly varied and experienced in divergent ways by different people; both within places and between varied geographic environments. Here, examining the three-dimensional dialectics of suburban infrastructure not only functions as a heuristic device but presents flexible conceptual and comparative tools capable of adapting to the distinct ways in which infrastructures are constructed as problems and potential solutions within the polycentric and highly differentiated milieu of global suburbia. Moreover, the essential relationships captured by the conceptual triads have a broader applicability for other studies of urban infrastructure beyond specific instances of the suburban.

In concluding, and as a prolegomenon to a future research agenda, it is worth considering how we can think about infrastructure for suburbs in an alternative, progressive manner; opening spaces for access, equity, empowerment. Unpacking the unequal power relations and differential knowledges of suburban infrastructure through the framework presented above elevates issues of 
scale, centrality and marginalization in the study of suburban infrastructures. The dynamic and evolving nature of suburban space invokes new risks and vulnerabilities. The rising racialization and suburbanization of poverty are now strongly associated with many inner suburban areas in the Global North where the combination of immigration, renter status, and visible minority membership - as well as gender - has become a predictor of structural inequality (Dikeç 2007; Hanlon 2008; Lo et al. 2015; Vicino 2013). In the Global South, informal settlements, gated communities, perennial periurbanization, and social segregation present alternate challenges for those seeking to foster socially equitable suburban processes (Amin 2014; Kaker 2014; McFarlane et al. 2014; Simone 2004). There is a necessary infrastructural dimension to attempts to empower, enfranchise, and integrate peripheral areas amidst the maelstrom of global suburbanization. This involves rethinking how the morphologies and sociologies of infrastructure can introduce new social centralities into socially and spatially marginalized places that can address the compartmentalization, segregation, and atomism equated with ideational and experienced suburbanisms (Walks 2013a). As Lefebvre put it: The form of critique must illustrate ever more profoundly that urban centers are multifunctional. Furthermore, it must not hide the problems. If there are contradictions in the use of space, they also appear at this level, and urban centrality cannot be presented, supported, or propounded without recognizing the problems. There are dialectical disturbances, displacements of centrality; there is saturation, the self-destruction of centrality, from which perhaps will come the need for polycentrality, for a polycentric conception of urban space $(2009,176)$.

Assessing the challenges and potentiality of infrastructure for global suburbs can then point towards the capacity to produce suburban space and control of the process of suburbanization to new, socially just ends. Analyzing how differing infrastructures condition concurrent social centralities at different scales, and the potential repercussions for suburban inhabitants' spatial and political 
practices, is a vital step in this process. Although people can use infrastructures in adaptive and transformative ways, it is important to note that they do not do so under conditions of their own choosing. Given the massive capital (including social capital) embedded within infrastructure and the monumental aegis of the state is shaping their production and governance, the spatial fixes of previous generations burden, like a mountain, the spatial practices of those living in the present. The size and scale of many suburban infrastructural artifacts and the extended landscapes they support, for instance, pose a basic challenge for those looking to densify or retrofit spaces on the urban periphery away from auto-centric ways of life while improving access and connectivity for social marginalized communities (see Grant et al. 2013). But mobilizing the conceptual framework presented here, I argue, opens a means to theorize how public/private individual/collective actors operating across multiple scales articulate and operationalize claims to 'the right to suburbs' in practice (see Carpio et al. 2011). Such claims may emerge in the guise of successionist politics grounded in homeownership, private property rights, and a pervasive neoliberal suburban spatial polity. But they may also point to moments of political action and grassroots mobilization capable of transforming peripheral urban areas by extending the struggle against exclusions from space. To uncover what social relations are internalized in (sub)urban space, and how they are internalized, as Merrifield $(2006,108)$ surmises, "is to learn how to produce something better, is to learn how to produce another city, another space, a space for and of socialism". With this, suburban infrastructure emerges as a crucial context and vital mechanism underpinning a progressive polycentric suburban spatial polity, one positioned between the overarching tensions of centrifugal and centripetal global urbanization. 


\section{Figures and tables:}

Figure 1: Infrastructure as artifacts and systems in relation to suburban space

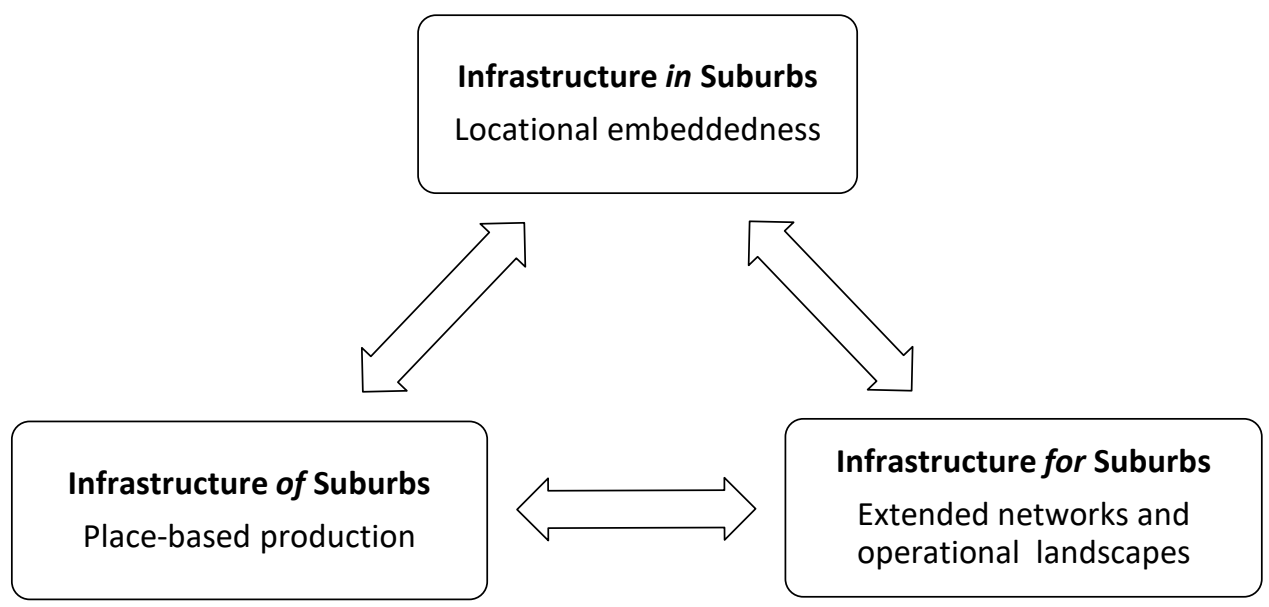

Figure 2: Suburban processes internalized by infrastructure

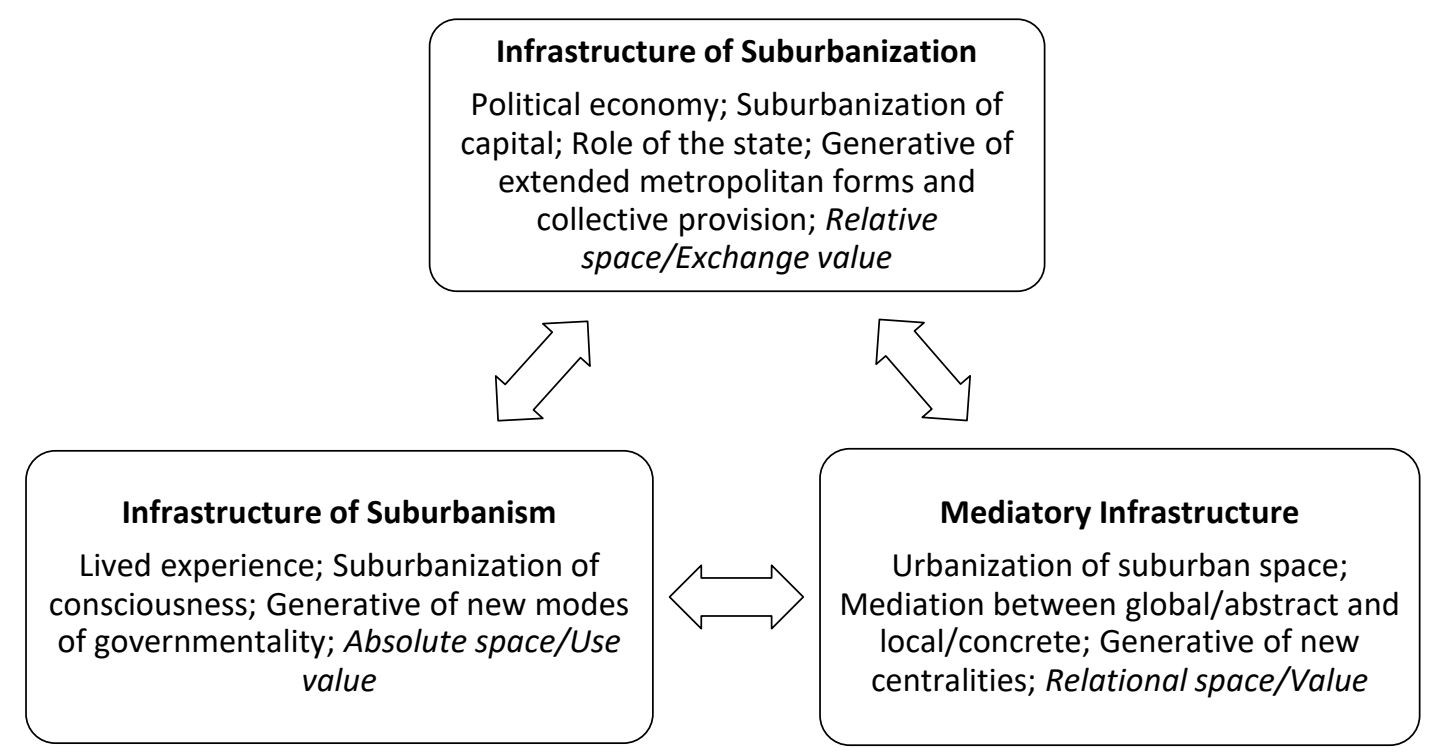


Table 1: Matrix of suburban infrastructure

\begin{tabular}{|c|c|c|c|}
\hline & $\begin{array}{l}\text { Infrastructure of } \\
\text { Suburbanization }\end{array}$ & $\begin{array}{l}\text { Infrastructure of } \\
\text { Suburbanism(s) }\end{array}$ & $\begin{array}{c}\text { Mediatory } \\
\text { Infrastructure }\end{array}$ \\
\hline $\begin{array}{l}\text { Infrastructure } \\
\text { in Suburbs }\end{array}$ & $\begin{array}{l}\text { Higher order infrastructures as } \\
\text { they facilitate suburban } \\
\text { expansion: } \\
\text { Splintered premium networks, } \\
\text { bypasses (uneven } \\
\text { development); National } \\
\text { electricity grid, power cables, } \\
\text { fiber optics etc.; International } \\
\text { airports; Infrastructure } \\
\text { produced, maintained and } \\
\text { governed by higher order } \\
\text { agencies/scales, but facilitating } \\
\text { suburban expansion; Residual } \\
\text { elements of previous spatial } \\
\text { fixes, remnant space of } \\
\text { Fordism }\end{array}$ & $\begin{array}{l}\text { Higher order infrastructures as } \\
\text { they shape suburban life: } \\
\text { Post-suburban growth/mobility } \\
\text { hubs ('urbanity' via densification); } \\
\text { Car parks and big box retail power } \\
\text { centers promoting new } \\
\text { consumption practices; Residential } \\
\text { HEI campuses and studentification, } \\
\text { town/gown conflicts; Greenbelts; } \\
\text { Residual elements of previous } \\
\text { spatial fixes (path dependent social } \\
\text { practice); Infrastructures as } \\
\text { alienating, (dis)connecting; Sites of } \\
\text { risk, vulnerability, and opportunity }\end{array}$ & $\begin{array}{l}\text { Higher order infrastructures } \\
\text { integrating suburbs into broader } \\
\text { networks (and vice versa): } \\
\text { National highway networks; } \\
\text { Airports; Trunk rail lines; Global } \\
\text { logistics centers and intermodal } \\
\text { terminals; Infrastructure as } \\
\text { symbolic markers; Corporate } \\
\text { headquarters/science } \\
\text { parks/office campuses; Suburbs } \\
\text { as a fix for national housing } \\
\text { crises; Acts of bounding, } \\
\text { enclosure, separation (within the } \\
\text { context of post-metropolitan } \\
\text { and postcolonial urbanization) }\end{array}$ \\
\hline $\begin{array}{l}\text { Infrastructure } \\
\text { of Suburbs }\end{array}$ & $\begin{array}{l}\text { Place-based infrastructures } \\
\text { supporting suburban growth: } \\
\text { Streets, sewers, bus routes etc. } \\
\text { developed, maintained, and } \\
\text { governed by local authorities; } \\
\text { Claims over territory and } \\
\text { growth-oriented politics; } \\
\text { Special taxing districts; TIFs, tax } \\
\text { breaks and financial incentives } \\
\text { for developers; Housing } \\
\text { development (physical form) } \\
\text { and planning codes (regulatory } \\
\text { institutions); Local rezoning to } \\
\text { support commercial and } \\
\text { housing development }\end{array}$ & $\begin{array}{l}\text { Place-based infrastructure as they } \\
\text { shape everyday spatial practice: } \\
\text { Suburban community and advocacy } \\
\text { groups; Appropriation and } \\
\text { reimagining of (formal and } \\
\text { informal) built forms and } \\
\text { institutions by suburban } \\
\text { inhabitants; Implementation of } \\
\text { informal sanitation systems in } \\
\text { peripheral urban areas of the } \\
\text { global South; Desire lines; } \\
\text { Gerrymandering; Car-pooling; } \\
\text { Wired connectivity as community; } \\
\text { Suburbanity as perceived, lived by } \\
\text { suburban inhabitants; Utopian } \\
\text { imaginaries of suburban life, the } \\
\text { suburbs marketed as refuge and } \\
\text { escape from the city }\end{array}$ & $\begin{array}{l}\text { Use of place-based } \\
\text { infrastructures as spaces of } \\
\text { mediation, centrality, } \\
\text { difference: } \\
\text { Adapting strip malls for } \\
\text { transnational cultural } \\
\text { networking and events; } \\
\text { Utilization of remnant spaces of } \\
\text { Fordism for new, just-in-time } \\
\text { practices (new territorialities and } \\
\text { topologies); Position of suburban } \\
\text { institutions in urban/global } \\
\text { governance mosaic; Local } \\
\text { partnerships to access national } \\
\text { government financing; Inter- } \\
\text { suburban economic } \\
\text { competitiveness, attempts to } \\
\text { locally capture global capital }\end{array}$ \\
\hline $\begin{array}{l}\text { Infrastructure } \\
\text { for Suburbs }\end{array}$ & $\begin{array}{l}\text { Sites and spaces of extended } \\
\text { (sub)urbanization: } \\
\text { Reservoirs and pipeline in non- } \\
\text { local watersheds; Auto- } \\
\text { manufacturing centers, } \\
\text { subsidies for cheap oil/gas; } \\
\text { Institutions of financialization, } \\
\text { mortgage companies; Private } \\
\text { property rights and legal } \\
\text { arrangements; Regional or } \\
\text { national planning bodies and } \\
\text { strategies; Federal/State } \\
\text { support for homeownership, } \\
\text { construction of new } \\
\text { sustainable housing stock; } \\
\text { Growth-oriented projects } \\
\text { stressing 'quality of life' }\end{array}$ & $\begin{array}{l}\text { Extended infrastructures } \\
\text { structuring suburban ways of life: } \\
\text { The development of political } \\
\text { movements to address } \\
\text { peripheralization, automobilities } \\
\text { etc, at multiple scales; Lobbying } \\
\text { around the 'war on cars'; Struggles } \\
\text { over appropriate forms of } \\
\text { transport, service provision; } \\
\text { Regional commuter-sheds; Google } \\
\text { buses; Commodification of distant } \\
\text { resources (oil fields, rainforests) in } \\
\text { order to meet demands of } \\
\text { suburban lifestyles; Media } \\
\text { representation from televisions } \\
\text { and Hollywood (US commercial film } \\
\text { industry) }\end{array}$ & $\begin{array}{l}\text { Extended infrastructure of } \\
\text { suburban (dis)connectivity: } \\
\text { Suburbanity as relational; } \\
\text { Integration into global flows for } \\
\text { suburban capital; Mechanisms } \\
\text { articulating suburban labor } \\
\text { markets into wider networks; } \\
\text { Topological connectivity; Co- } \\
\text { constituted suburbs and the } \\
\text { spaces they support; Expressway } \\
\text { off-ramps; Resource wars; Global } \\
\text { financial and regulatory } \\
\text { agreements (coordinated } \\
\text { through the IMF, OECD, EU etc.); } \\
\text { Potentiality of the 'right to the } \\
\text { suburbs' }\end{array}$ \\
\hline
\end{tabular}




\section{References:}

Addie J-P D 2014 Flying high (in the competitive sky): conceptualizing the role of airports in global city-regions through "aero-regionalism" Geoforum 55(1) 87-99

Amin A 2014 Lively infrastructure Theory, Culture \& Society 31(7/8) 239-258

Angelo H and Hentschel C 2015 Interactions with infrastructure as windows into social worlds: a method for critical urban studies City 19(2-3) 306-312

Atkinson A 2007 Cities after oil: background to the collapse of "modern" civilization City 11(3) 293312

Beauregard R 2006 When America became Suburban University of Minnesota Press, Minneapolis

Bennett J 2005 The agency of assemblages and the North American Blackout Public Culture 17(3) 445-465

Bjorvatn K 2000 Urban infrastructure and industrialization Journal of Urban Economics 48(2) 205-218

Brenner N ed 2014 Implosions/Explosions: Towards a Study of Planetary Prbanization Jovis, Berlin

Brenner N and Schmid C 2014 The 'urban age' in question International Journal of Urban and Regional Research 38(3) 731-755

Brenner N and Schmid C 2015 Towards a new epistemology of the urban? City 19(2-3) 151-182

Burcell R W, Downs A, McCann B and Mukherji S 2005 Sprawl Costs: Economic Impacts of Unchecked Development. Island Press, Washington D.C.

Carpio G, Irazabel C and Pulido L 2011 Right to the suburb? Rethinking Lefebvre and immigrant activism Journal of Urban Affairs 33(2) 185-208

Cidell J 2011 Distribution centers among the rooftops: the global logistics network meets the suburban spatial imaginary International Journal of Urban and Regional Research 35(4) 832-851

Charmes E and Keil R 2015 The politics of post-suburban densification in Canada and France International Journal of Urban and Regional Research 39(3) 581-602

Chattopadhyay S 2012 Unlearning the City: Infrastructure in a New Optical Field University of Minnesota Press, Minneapolis

Cochrane A, Colenutt B and Field M 2015 Living on the edge: building a sub/urban region Built Environment 41(4) 567-578

Coutard O 2008 Placing splintering urbanism Geoforum (39(6) 1815-1950

D'Hooghe A 2011 The objectification of infrastructure: elements of a different space and aesthetic for sububan America Projections: The MIT Journal of Planning 10, 85-93

Dikeç M 2007 Badlands of the Republic: Space, Politics and Urban Policy. Blackwell, Malden

Dodson J 2014 Suburbia under an energy transition: a socio-technical perspective Urban Studies 51(7) 1487-1505

Dourish P and Bell G 2007 The infrastructure of experience and the experience of infrastructure: meaning and structure in everyday encounters with space Environment \& Planning B: Planning and Design 34(3) 414-430

Easterling K 2014 Extrastatecraft: The Power of Infrastructure Space. Verso, London

Ekers M, Hamel P and Keil R 2012 Governing suburbia: modalities and mechanisms of suburban governance Regional Studies 46(3) 405-422

Farias I 2011 The politics of urban assemblages City 15(3-4) 365-374

Fernado J 2015 Why Heathrow got the nod from the Airports Commission report The Conversation. (https://theconversation.com/why-heathrow-got-the-nod-from-the-airports-commissionreport-44149) Accessed 14 August 2015

Filion P 2015 Suburban inertia: the entrenchment of dispersed suburbanism International Journal of Urban and Regional Research 39(3) 633-640

Fishman R 1987 Bourgeois Utopias: The Rise and Fall of Suburbia. Basic Books, New York 
Gandy M 2003 Concrete and Clay: Reworking Nature in New York City MIT Press, Cambridge

Garreau J 1991 Edge City: Life on the New Frontier Doubleday, New York

Graham S ed 2010 Disrupted Cities: When Infrastructure Fails Routledge, New York

Graham S and Marvin S 2001 Splintering Urbanism: Networked Infrastructures, Technological Mobilities and the Urban Condition Routledge, New York

Graham S and McFarlane C eds 2015 Infrastructural Lives: Urban Infrastructure in Context Routledge, New York

Grant J L, Nelson A C, Forsyth A, Thompson-Fawcett M, Blais P and Filion P 2013 The future of the suburbs. suburbs in transition / The resettlement of America's suburbs /

Suburbs in global context: the challenges of continued growth and retrofitting / Suburban urbanity: re-envisioning indigenous settlement practices / Toward a new suburban America: will we catch the wave / Optimistic and pessimistic perspectives on the evolution of the North American suburb / Response Planning Theory and Practice 14(3) 391-415

Hamel P and Keil R eds 2015 Suburban Governance: A Global View. University of Toronto Press, Toronto

Hanlon B 2008 The decline of older, inner suburbs in metropolitan America Housing Policy Debate, 19(3) 423-456

Harris R 2006 Unplanned Suburbs: Toronto's American Tragedy, 1900 to 1950. Johns Hopkins University Press, Baltimore

Harris R 2010 Meaningful types in a world of suburbs in Clapson $\mathbf{M}$ and Hutchinson $\mathbf{R}$ eds Suburbanization in Global Society Emerald Group, Bingley 15-48

Harvey D 1985 The Urbanization of Captial Johns Hopkins University Press, Baltimore

Harvey D 1996 Cities or urbanization? City, 1(1-2) 38-61

Harvey D 2006 Space as a keyword in Castree N and Gregory D eds David Harvey: A Critical Reader Blackwell, Malden 270-294

Hayden D 2003 Building Suburbia: Green Fields and Urban Growth, 1820-2000. Pantheon, New York

Henderson J 2015 From climate fight to street fight: the politics of mobility and the right to the city in Cidell J and Prytherch D eds Transport, Mobility, and the Production of Urban Space Routledge, New York 101-116

Höhne S 2015 The birth of the urban passenger: infrastructural subjectivity and the opening of the New York City subway City 19(2-3) 313-321

Howe C, Lockrem J, Appel H, Hackett E, Boyer D, Hall R, Schneider-Mayerson M, Pope A, Gupta A, Rodwell E, Ballestro A, Durbin T, el-Dahdah F, Long E, Mody C 2015 Paradoxical infrastructures: ruins, retrofit, and risk Science, Technology, and Human Values (early view) doi: 10.1177/0162243915620017

Jessop B 2000 The crisis of the national socio-temporal fix and the tendential ecological dominance of globalizing capitalism International Journal of Urban and Regional Research 24(2) 323-360

Jessop B, Brenner N and Jones M 2008 Theorizing sociospatial relations Environment and Planning D: Society and Space 26(3) 389-401

Kaker S A 2014 Enclaves, insecurity and violence in Karachi South Asian History and Culture 5(1) 93107

Kantor P and Savitch H 2005 How to study comparative urban development politics: a research note International Journal of Urban and Regional Research 29(1) 135-151

Keil R ed 2013 Suburban Constellations: Governance, Land and Infrastructure in the 21st Century Jovis, Berlin

Keil R and Young D 2008 Transportation: the bottleneck of regional competitiveness in Toronto Environment and Planning C: Government and Policy 26(4) 728-751

Keil R and Young D 2009 Fringe explosions: risk and vulnerability in Canada's new in-between urban landscape Canadian Geographer 53(4) 488-499 
Knight E R W and Sharma R 2015 Infrastructure as a traded product: a relational approach to finance in practice Journal of Economic Geography (early view) doi: 10.1093/jeg/lbv039

Knox P L 2008 Metroburbia, US A. Rutgers University Press, Picastaway

Law M J 2012 'The car indispensible’: the hidden influence of the car in inter-war suburban London Journal of Historical Geography 38(4) 424-433

Lefebvre H 1991 The Production of Space Blackwell, Oxford

Lefebvre H 2003 The Urban Revolution University of Minnesota Press, Minneapolis

Lefebvre H 2009 State, Space, World: Selected Essays University of Minnesota Press, Minneapolis

Li W 2009 Ethnoburb: The New Ethnic Community in Urban America. University of Hawai'i Press, Honolulu

Lo L, Preston V, Anisef P, Basu R and Wang S 2015 Social Infrastructure and Vulnerability in the Suburbs University of Toronto Press, Toronto

MacCleery R, Peterson C and Stern J D 2012 Shifting Suburbs: Reinventing Infrastructure for Compact Development Urban Land Institute, Washington D.C.

Mayer M 2008 To what end do we theorize sociospatial relations? Environment and Planning D: Society and Space 26(3) 414-419

McFarlane C 2011 Assemblage and critical urbanism. City 15(2) 204-224

McFarlane C, Desai R and Graham S 2014 Informal urban sanitation: everyday life, poverty and comparison Annals of the Association of American Geographers 104(5) 989-1011

McFarlane C and Rutherford J 2008 Political infrastructures: governing and experiencing the fabric of the city International Journal of Urban and Regional Research 32(2) 363-374

Mees P 2010 Transport for Suburbia: Beyond the Automobile Age Earthscan, Sterling

Merrifield A 2002 Dialectical Urbanism: Social Struggles in the Capitalist City Monthly Review Press, New York

Merrifield A 2006 Henri Lefebure: A Critical Introduction Routledge, New York

Merrifield A 2013 The Politics of the Encounter: Urban Theory and Protest under Planetary Urbanization University of Georgia Press, Athens

Miller J 2013 Infrastructure 2013: Global Priorities, Global Insights Urban Land Institute and Ernst \& Young, Washington D.C.

Ollman B 2003 Dance of the Dialectic: Steps in Marx's Method University of Illinois Press, Urbana

Peck J 2011 Neoliberal suburbanism: frontier space Urban Geography 32(6) 884-919

Phelps N A, Wood A and Valler D 2010 A post-suburban world? An outline of a research agenda Environment and Planning A 42(2) 366-383

Quinby R 2011 Time and the Suburbs: The Politics of Built Environments and the Future of Dissent Arbeiter Ring, Winnipeg

Rees W E 1992 Ecological footprints and appropriated carrying capacity: what urban economics leaves out Environment and Urbanization 4(2) 121-130

Robinson J 2011 Cities in a world of cities: the comparative gesture International Journal of Urban and Regional Research 35(1) 1-23

Robinson J 2015 Comparative urbanism: new geographies and cultures of theorizing the urban International Journal of Urban and Regional Research (early view) doi: 10.1111/1468-2427.12273

Rutherford J 2008 Unbundling Stockholm: the networks, planning and social welfare nexus beyond the unitary city Geoforum 39(6) 1871-1883

Sayer A 1992 Method in Social Science Routledge, New York.

Schmid C 2008 Henri Lefebvre's theory of the production of space: towards a three-dimensional dialectic in Goonewardena K, Kipfer S, Milgrom R and Schmid C eds Space, Difference, Everyday Life: Reading Henri Lefebure Routledge, New York 27-45 
Siemiatycki M 2013 The global production of transportation public-private partnerships. International Journal of Urban and Regional Research 37(4) 1254-1272

Sieverts T 2003 Cities without Cities: An Interpretation of the Zwischenstadt. Spon Press, London

Simone A M 2004 People as infrastructure: intersecting fragments in Johannesburg Public Culture, 16(3) 407-429

Simone A M 2015 Come on out, you're surrounded: the betweens of infrastructure City 19(2-3) 375383

Smart Commute 2014 Smart Commute (http://www.smartcommute.ca/en/home) Accessed 31 May 2014

Soll D 2012 City, region and in between: New York City's water supply and the insights of regional history Journal of Urban History 38(2) 294-318

Stanilov K and Scheer B C eds 2004 Suburban Form: An International Perspective Routledge, New York

Swyngedouw E 2004 Social Power and the Urbanization of Water: Flows of Power. Oxford University Press, Oxford

Teaford J 1997 Post-Suburbia: Government and Polities in Edge Cities. Johns Hopkins University Press, Baltimore

Tonkiss F 2015 Economies of infrastructure City 19(2-3) 384-391

Torrance M I 2008 Forging global governance? Urban infrastructures as networked financial products International Journal of Urban and Regional Research 32(1) 1-21

Urry J 2003 Global Complexity Polity, Cambridge

Vaughan L, Griffiths S, Haklay M, and Jones C E 2009 Do the suburbs exist? Discovering complexity and specificity in suburban built form Transactions of the Institute of British Geographers 34(4) 475-488

Vicino T J 2013 Suburban Crossroads: The Fight for Local Control of Immigration Policy. Lexington Books, Plymouth

Walks R A 2013a Suburbanism as a way of life, slight return. Urban Studies 50(8) 1471-1488

Walks R A 2013b Mapping the urban debtscape: the geography of household debt in Canadian cities Urban Geography 34(2) 153-187

Walks R A 2014 Canada's housing bubble story: mortgage securitization, the state, and the global financial crisis International Journal of Urban and Regional Research 38(1) 256-284

Walks R A 2015 Stopping the 'War on the car': neoliberalism, Fordism, and the politics of automobility in Toronto Mobilities 10(3) 402-422

Warner S B 1978 Streetcar Suburbs: The Process of Growth in Boston, 1870-1900 Havard University Press, Cambridge

Young D, Wood P and Keil R eds 2011 In-Between Infrastructure: Urban Connectivity in an Age of Vulnerability Praxis (e)Press, Keolowna

Acknowledgements: This article was first presented at the 'Infrastructure Problems and Solutions in the Global Suburb' Global Suburbanisms Workshop organized by Pierre Filion and Roger Keil and held at the University and Waterloo in June 2015. I have benefited from the comments of those attending the workshop, and would like to extend my thanks in particular to Alan Walks, Pierre Filion, Roger Keil, Simon Marvin, Rebecca Ince, David Wachsmuth, Frederick Peters, Markus Moos, and Jonathon Rutherford for their encouragement and incisive feedback on previous versions of the paper. I also wish to thank the anonymous reviewers for their constructive suggestions. All errors and omission remain the responsibility of the author. 
